\title{
The Role of Social CRM in Social Information Systems: Findings from Four Case Studies
}

\author{
Olaf Reinhold \\ Leipzig University \\ reinhold@,wifa.uni-leipzig.de
}

\author{
Rainer Alt \\ Leipzig University \\ alt@wifa.uni-leipzig.de
}

\begin{abstract}
Social Information Systems (SIS) are larger systems of open and voluntary collaboration between involved parties and based on Social Media. Recent research about SIS describes characteristics, constituting elements and research streams. However, detailed analysis about the effects and system design of SIS are still limited. This paper investigates the concept of SIS from the perspective of Customer Relationship Management (CRM). It illustrates similarities and differences between SIS and Social CRM implementations by drawing on existing research and the examination of four cases studies. The findings show benefits and requirements for the adoption of SIS in the field of CRM. On one hand, SIS provide new means for CRM by fostering the creation and nurturing of relationships between business and the market. On the other hand, for realizing these opportunities companies need to further integrate Social Media, CRM and Social CRM from an inside-out and outside-in perspective.
\end{abstract}

\section{Introduction}

Boundaries between Information Systems (IS) are vanishing. Customer Relationship Management (CRM) systems cannot be regarded as closed internal systems anymore [1]. Through Social Media platforms, customers not only provide a mass of profile data, but also interact directly and indirectly with businesses [2]. Thus, empowering the customers and giving them more control over the communication and relationship [3]. Social CRM already addresses this change by linking these platforms with CRM systems and processes $[4,5]$. However, this concept still applies an internal/business to external/customer perspective (insideout). A great potential may arise from understanding $\mathrm{CRM}$ as a collaborative approach, which builds upon joint activities between businesses and customers (and adding an outside-in perspective) within integrated platforms [1]. Thus forming a Social Information System (SIS), which are "information systems based on social technologies and open collaboration" [6]. Unlike
Social CRM, SIS are not focused on a specific application area and they can be found inside of companies (e.g. knowledge management), at the intersection of internal and external processes (e.g. marketing) and outside of companies (e.g. co-creation processes). The concept of SIS [6] aims to address both perspectives and may help in the design of decentralized and collaborative CRM systems, with actors from inside of a company and from the surrounding market. Thus, they may help in strengthening the ties with customers as well as to build up bridges into other communities [7], resulting in a community based CRM with members that support each other, provide input for innovations and give access to competencies.

However, while a lot of research deals with the application and effects of Social Media in business, inside of companies and customer-facing, research that combines the internal and external perspectives as suggested by SIS seems immature and fragmented $[8,9]$. Schlagwein et al. [6] pointed out this shortcoming in a comprehensive literature research and called for more research about the design, building and leveraging of SIS (see also [10, 11]). Wehner et al. [12] recently reaffirmed the need for further research on the design of such systems and insights into the benefit of their use.

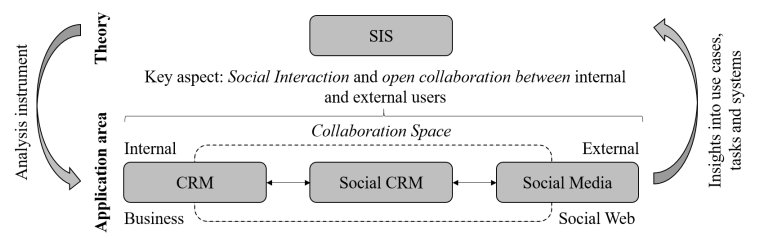

Figure 1. Research focus and approach

In general, SIS have strong overlaps with Social Media, CRM and Social CRM in the field of customeroriented processes. The question arises if Social CRM systems are sufficient for establishing such SIS. Two major elements of SIS are social interaction and open collaboration between internal and external users. However, a clear conceptual foundation of SIS is currently missing [8] and insights from industry cases are limited. Existing research on SIS describes features and first frameworks (see $[6,13]$ ), but these contribu- 
tions are on a general level regarding the implementation and the specific impact on business processes.

This paper addresses these shortcomings with an exploratory study of literature and cases. The research objective is to provide a better understanding about the role of Social CRM in SIS. The research questions (RQ) are: (RQ1) How is the SIS concept linked with existing Social CRM concepts, including Social Media and CRM? (RQ2) How do companies realize SIS with Social CRM on the strategy, organization, process and system level? (RQ3) How contributes Social CRM to SIS?

For answering these research questions, the concept and approaches for linking CRM with the Social Web are evaluated from the perspective of SIS and Social CRM. Based on these findings, an analysis instrument for an exploratory qualitative analysis [14] about the role of Social CRM in SIS is constructed (Figure 1) and applied to four cases. This analysis provides insights into the role of involved elements, the design, the role of Social CRM and the contribution of SIS.

\section{Examining the role of SIS and Social CRM}

\subsection{Concept and building blocks of Social CRM}

The concept of CRM combines customer-oriented strategies with technologies and aims at long-term profitable relationships [3]. CRM maybe defined as a "process that utilizes technology as an enabler to capture, analyse and disseminate current and prospective customer data to identify customer needs more precisely and to develop insightful relationships" [15]. The strategic goals of CRM are executed through CRM processes for marketing, sales and service purposes [16]. Gebert et al. [17] names six key processes: campaign management, lead management, offer management, contract management, complaint management, and service management that structure CRM processes along the customer activity cycle [18]. CRM systems [19] provide functionalities to collect customer related data within the organization, to manage CRM processes and to learn and optimize an organization from a customer-centric view. They comprise operational, analytical, communicative and collaborative system components [20]. Successful CRM implementations aim for a high customer orientation enabled by a high integration of processes and systems [21, 41].

Social Media can be defined as web-based internet applications that allow the creation, access, and exchange of user-generated content (UGC) [3]. Kaplan et al. [22] propose a classification for Social Media which encompasses among others blogs/microblogs, social networking sites (e.g. Facebook), content communities, virtual worlds and collaborative projects. From a more general perspective, a set of Web 2.0 services that define the features of individual platforms can be differentiated: blogs including microblogs, social networking, sharing platforms, syndication, wiki's and forums. Social Media have introduced new customer-centric tools that empower customers to interact with each other and with businesses for exchanging information, resources and co-creating value $[23,5]$. Trainor et al. [24] name conversation, sharing, groups and relationships as key building blocks of Social Media that influence CRM. Faase et al. [25] identified that an added value of Web 2.0 in CRM may be observed in the field of customer behaviour, customer interaction, marketing and customer life-time value.

Social CRM describes measures that use Social Media technologies within the planning, implementation and control of CRM activities (see [3, 26, 27, 4, $28,29])$. The term Social CRM denotes a customeroriented concept that integrates Social Media with CRM applications in the area of marketing, sales and service (see [3, 4, 28]). Although Social CRM overlaps with other terms, such as social commerce, Social Media marketing or social networks, it focuses on leveraging the Social Web for CRM purposes. Faase et al. [25] define Social CRM as "about creating a two-way interaction between the customer and the firm" and as "a CRM strategy that uses Web 2.0 services to encourage active customer engagement and involvement". Social CRM has proven as viable instrument for building and utilizing strong and weak relationship ties [30]. The Social CRM capabilities of a company are defined in the field of culture, information management, internal business processes, and customer-oriented processes [24]. Reinhold et al. [31] illustrated with a multi-case study that the CRM processes of campaign, lead, offer, service, complain and feedback management can be closely linked with Social Media. A number of researchers investigated the architectures of Social CRM from different perspectives $[4,29,32,5,33]$ that this research can draw upon.

Engagement is a core principle of CRM [34] and at the base of value creation [33]. Kunz et al. [33] propose a typology of engagement in the digital world. Following this typology, engagement can be passive, customer-driven or firm-driven, but true collaborative engagement occurs only in web forum, firm created online community, idea contest, wearables or webinar. Value through cooperation emerges in the joint interaction between the customer and firm, but also in customers individual and social behaviour in the customer domain [35, 1]. While CRM implementations build upon an inside-out perspective of companies on their 
market, Social CRM promotes the understanding that the market, including customers, experts, partners and even competitors, is an active part of CRM. However, often the firm-perspective is dominant in IS focused research about Social CRM [33]. Research about systems for Social CRM is mainly based on the assumption that companies implement a Social CRM system for managing all relevant processes such as Social Media integration, analysis or interaction. On the contrary, Social Media platforms such as Facebook are built around the user processes and provide additional features for companies and their CRM processes, such as market segmentation, campaign planning, customer interaction.

\subsection{Concept and features of SIS}

Letch [36] denotes that SIS can be understood in two ways. First, they may "refer to the communicative aspects of information systems and how technologies facilitate interaction and communication within networks of participants - for example systems which make predominant use of Social Media". Second, the term social may refer "to society at large rather than interaction and communication" with a "focus on applying information technologies to improve problems in society". This research applies the first direction.

Schlagwein et al. [6] note that SIS shift the core system function of information systems from work support to online social interaction (e.g., the system allows for comment, rating, "friending," and similar feedback mechanisms) or open collaboration (i.e., the number of contributors or participants in the system is not predefined). The basis of these systems consists of social computing tools such as Social Media [22]. For enriching the understanding of SIS as larger systems that are interconnected with the processes in organizations, Schlagwein et al. [6] suggests a system perspective [37]. Processes studied in research on SIS can be categorized into (1) user co-creation processes, (2) research and development-focused processes, (3) production-focused processes, (4) marketing-focused processes, and (5) firm-internal knowledge sharing processes [6]. An analysis of the different researchstreams related to SIS points to the same direction [8]. Following this concept, SIS may address the business processes of an organization either as a whole or as certain functions [9]. For CRM the co-creation processes, firm-internal knowledge sharing processes and marketing-focused processes are most the relevant categories. The later should comprise the areas of marketing, sales and (after-sales) service. Schlagwein et al. [6] summarized six distinctive features of SIS: sociality, openness, contributors, contents, technology and locations. However, the business value of such sys- tems, building blocks and the contribution to specific processes and service of a company remain vague.

By providing a basis for social interaction and open collaboration, SIS can foster the creation of strong ties between business and customers [30]. Strong ties are essential for real communities, but "these are typically groups with a great deal of similarity and, as such, less likely than more tenuous connections to carry new information and perspectives to their groups" [7]. However, SIS are also providing a context for the forming of weak ties [7] that are more likely to be bridges between people. For example, relationships between businesses and followers, experts or other parties that are related with the business may have a high value as bridges to other communities with new views, information or competencies. Both kinds of relationship ties are important for achieving the goals of SIS and CRM.

\subsection{Similarities and differences between SIS and Social CRM}

CRM, Social CRM and Social Media are closely linked with each other. CRM systems are company owned systems that support CRM processes. Social CRM aims at incorporating Social Media in CRM. CRM and Social CRM represent the firm perspective, where the potential for open and voluntary interaction with external actors is limited compared to Social Media. However, increasingly open web-based platforms (e.g. Social Networks, Influencer Marketplaces, Knowledge Communities) also support these processes and the line between firm and customer perspective is blurring. Nevertheless, these systems lack integration, for which currently Social CRM systems are used.

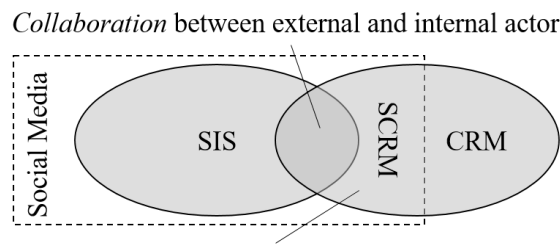

Integration of Social Media with the CRM

Figure 2. Links between concepts and terms

SIS put the collaboration and engagement inside and outside of a company in the focus (see Figure 2). CRM related scenarios are only one application field [6]. For realizing a SIS, the platforms and systems need to be incorporated and governed $[8,38]$ as comparison with the features that SIS [6] illustrate (see Table 1). Consequently, the three IS can be seen as interconnected pillars of an SIS that addresses customer-facing processes, provides the basis for social interaction and open collaboration between internal and external actors for the benefit of CRM strategies. Thus answering 
RQ1. SIS aim to exploit and deeply incorporate the potentials of Social Media for engagement from a bidirectional perspective $[34,33]$. They may provide new means for meaningful relationships with existing customers, connecting with new customers and improving the customer orientation of the service-system [35]. Prior research points out some of the potential effects
$[39,6,8,38,30,9]$ : fostering and utilizing of strong and weak ties with internal and external actors, the adding of an outside-in approach in processes and service delivery, the provision of missing information and competencies, the collaboration in processes and production, and an increase of the ability to innovate.

Table 1: Comparison of features of SIS in CRM systems, Social CRM tools and Social Media platforms

\begin{tabular}{|l|l|l|l|}
\hline Features & CRM & Social CRM & Social Media \\
\hline $\begin{array}{l}\text { Sociality (Community, } \\
\text { focus on information } \\
\text { exchange) }\end{array}$ & $\begin{array}{l}\text { Focus on information } \\
\text { storage, data is connected } \\
\text { for CRM processes }\end{array}$ & $\begin{array}{l}\text { Focus on information acquisition and in- } \\
\text { sights are linked with CRM }\end{array}$ & $\begin{array}{l}\text { Focus on information creation (UGC) } \\
\text { and exchange without domain specific } \\
\text { links between the data }\end{array}$ \\
\hline $\begin{array}{l}\text { Openness (large number } \\
\text { of users, voluntary } \\
\text { contributions) }\end{array}$ & $\begin{array}{l}\text { Restricted to employees } \\
\text { and formal processes for } \\
\text { contributions }\end{array}$ & $\begin{array}{l}\text { Restricted to employees, contributions are } \\
\text { acquired and are not necessarily voluntary } \\
\text { (e.g. data captured with monitoring) }\end{array}$ & $\begin{array}{l}\text { Users contribute voluntary, access to } \\
\text { UGC can be restricted by the platform } \\
\text { provider }\end{array}$ \\
\hline $\begin{array}{l}\text { Contributors (outside of } \\
\text { formal hierarchy, exter- } \\
\text { nals and employees) }\end{array}$ & Employees & Employees and selected external users & Users \\
\hline $\begin{array}{l}\text { Contents (user generat- } \\
\text { ed) }\end{array}$ & Employees create content \\
\hline $\begin{array}{l}\text { Technology (light } \\
\text { weight, flexible) }\end{array}$ & $\begin{array}{l}\text { Standard software. Exam- } \\
\text { ples are Microsoft Dynam- } \\
\text { ics CRM, Salesforce or } \\
\text { Oracle. }\end{array}$ & $\begin{array}{l}\text { Flexible tools that companies can integrated } \\
\text { with their CRM systems. Examples are } \\
\text { Synthesio, Lithium, or Falcon Social. }\end{array}$ & $\begin{array}{l}\text { Independent platforms that may pro- } \\
\text { vide access to their data for others } \\
\text { through API. Examples are Facebook, } \\
\text { Twitter, LinkedIn, Forums and Blogs. }\end{array}$ \\
\hline Locations & Internal, online and offline & Internal and external, online and offline & Internal and external, online \\
\hline
\end{tabular}

\section{Examination of four cases studies}

\subsection{Methodology}

Based on a case study research from 2011 to 2017 on the implementation of Social CRM [31], we selected for this research four case studies with a focus on ecommerce and examined them from the perspective of SIS. The cases have been selected as polar points of the featured integration degree of Social Media in CRM (low vs. high) and the size of the companies (small vs. large). Each case was based on semi-structured interviews of about 3 hours with managers and specialists from CRM related departments. These case studies were re-examined for this research. We used a twostage strategy for data analysis [14]. During the first stage, the within-case analysis of the data from each case study was undertaken guided by an analysis instrument (see 3.2). The occurrence of the measurement items was described or evaluated regarding a threepoint scale. The validity of the data was ensured through additional sources of evidence (e.g. examination of the services, white papers reports), reviews of case interpretations by interviewees and a chain of evidence provided by the case data. The second stage involved the cross-case analysis of the data, thus locating and examining similarities and differences across the four cases. In the process, the different approaches of the companies have been taken into account.

\subsection{An analysis instrument for the adoption of Social CRM and SIS}

Following Österle et al. [40], the three levels of strategy, process/organization and IS can be used for analysing and designing IS from a business perspective. This approach was used for structuring the analysis of Social CRM from an SIS perspective. Existing research (see 2.3) provides relevant measuring items on these levels (see Figure 3).

For analysing the degree to which a case features characteristics of SIS the items from Schlagwein et al. [6] were used. The organizational setting of an SIS involves coordination and the involvement of internal and external users [38]. The concept of integrated Social CRM provides items for assessing an implementation of Social CRM on the three levels [4, 31]. It depicts four different application areas of Social Media in CRM [31] where internal and external users and their content are integrated: establishing of a presence, enriching knowledge management, performing workflows and co-creation. Social interaction and open collaboration are the basis of different forms of engagement, which can be assessed through the platform examples of Kunz et al. [33] and by their relevance in the former application areas. The application of Social Media in CRM aims at the seven CRM processes [31] and their integration comprises five task areas, namely analysis, interaction, integration and management, Social Media and CRM [4]. The integration of CRM and Social Media in SIS on a technical level can be as- 
sessed by the workflow and data integration as well as the application of additional Social CRM systems [4, 42]. The later can be categorized in seven functional components: Social Search, Social Media Monitoring, Business Analytics, Social Network Analysis, Social Media Management and Community Management [4].

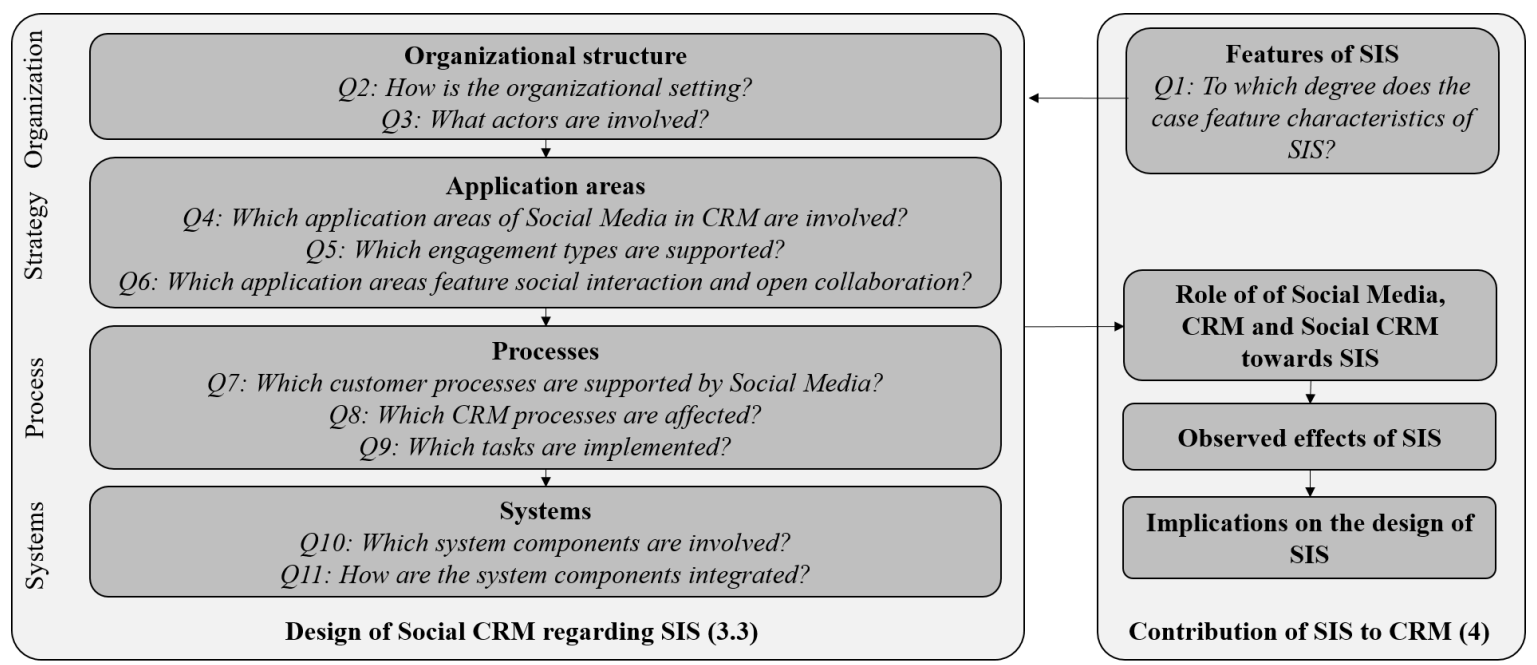

Figure 3. Conceptual model for the analysis of cases regarding the adoption of Social CRM and SIS

\subsection{Analysis and comparison of the cases}

Due to space limitations of this paper, the case descriptions and individual measures are not presented in detail. Table 2 provides a short overview about the companies and how they feature SIS (Q1). In the following, the observations regarding Q2-Q11 are summarized. Thus answering RQ2.

Organizational structure and role of users (refers to $Q 2$ and Q3). The cases feature different organizational setups. Spreadshirt, Cyberport and DT have dedicated employees for Social Media channels who manage the Social Media activities and connect internal employees on demand (e.g. a service manager for a specific problem or a sales representative for questions regarding offers). While larger companies such as Dell or DT created dedicated organizational structures and support teams, the two smaller companies have managers that coordinate the activities and information flows. Dell and Spreadshirt both show the aim to incorporate as many as possible employees into activities related to Social Media. Spreadshirt is partly involving other employees in Social Media activities. The approach of Dell with the incorporation of a large amount of employees into Social Media activities shows a different way. In both approaches, the employees get a training, but represent the company as individuals instead of anonymous service accounts or dedicated Social Media managers. The amount of processes that are integrated with Social Media correlates with the number of employees involved in Social Media activities. At the same time, both companies aim to incorporate external users to a larger extent (e.g. Customer survey and meetings, open platforms for collaboration) than Cyberport and DT. The organizational structure seems not to relate to company size or investments, but to the goal of "opening up" processes and involving customers in CRM processes. Thus showing the importance of weak ties for active communities [43] as well as the need for a managed approach [38].

Application areas of Social Media in CRM and role of social interaction and open collaboration (refers to Q4, Q5 and Q6). Almost every case addresses the four application areas at least to a medium degree. Dell and Spreadshirt show in specific areas even higher levels. All four companies maintain presences on several Social Media platforms and invite their users to interact on these platforms. If users start interactions, their aim is that an employee will answer and initiate further processes on demand.

Cyberport discusses openly the product range with customers. These social interactions help to provide rich information to other customers and to position the company as expert. Dell, Spreadshirt and DT discuss processes and products with customers even more intensely and across different platforms (e.g. Service forum, Spreadshirt Community, IdeaStorm, TelekomHelps). Spreadshirt and Dell also implemented approaches for collaborative work (e.g. to work together with customer in the solving of a service case or the development of product/design ideas).

In all four cases, the companies set up processes to actively stimulate the sharing of UGC with the aim to extend their reach into the contact network of their followers. This applies for the distribution of content, but also to the support of processes. Examples are the 
sharing of advertisements in marketing (e.g. DT creates viral marketing campaigns that involve contributions of pictures or stories by users), the distribution of offerings in sales (e.g. special offers of Dell that are distributed via Twitter and forwarded by followers to people without a prior relationship with Dell) or the distribution of solutions for service cases (e.g. DT creates videos that explain solutions to problems). All four cases provide users with the ability to link with each other and to share information about themselves. Activities of users influence the system and are reflected in the profile (e.g. activity degree of a user, if they have some kind of expert status, if they belong to a company or how helpful they were to other users). Users can connect with brands, presences or other users and open up their individual contact network for others. Often, a higher visibility and interaction is associated with internal platforms, but Spreadshirt or Cyberport show with Social Media logins or apps that profiles on external platforms can also be linked with internal platforms and processes.
The cases show that companies integrate their internal and external presences. While external presences are used for simple interactions, internal presences are used to manage complex collaboration processes and the social interactions. For example, Spreadshirt stimulates users to join the Spreadshirt forum or the DT invites users to discuss and solve their service topic on their own platforms instead of Facebook. At the same time the discussions and related UGC is a resource for knowledge management. All four companies learn through these discussions about market demands and customer satisfaction. In addition, Dell, Spreadshirt and DT actively stimulate the community with topics they would like to learn about and use the feedback in decision processes and process management.

The cases highlight the importance of external platforms for Social CRM [24] and that interactions among Social Web users, as well as opportunities for collaboration, contribute to CRM strategies [35]. However, related activities are often managed in specific teams and not within the existing CRM functions.

Table 2: Overview of the four cases

\begin{tabular}{|c|c|c|c|c|c|}
\hline & & Cyberport & Dell & Spreadshirt & DT \\
\hline & 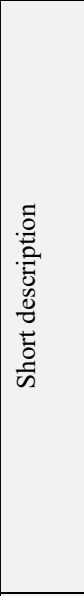 & $\begin{array}{l}\text { Founded 1998, Headquarter in } \\
\text { Dresden, Germany, } \\
640 \text { employees (2016). } \\
\text { Distributor for technology and } \\
\text { lifestyle products, such as note- } \\
\text { books, tablets, smartphones, pho- } \\
\text { tography, televisions and other } \\
\text { domestic appliances. Cyberport } \\
\text { operates an online shop } \\
\text { (www.cyberport.de), 15 depart- } \\
\text { ment shops and a distribution and } \\
\text { logistics centre. Cyberport has } \\
\text { started traditionally with CRM } \\
\text { and the implementation of pro- } \\
\text { cesses in marketing, sales and } \\
\text { services. Only later, they intro- } \\
\text { duced Social Media into these } \\
\text { processes by establishing a Social } \\
\text { Media Manager. }\end{array}$ & $\begin{array}{l}\text { Founded 1984, Headquarter in } \\
\text { Round Rock, U.S., } 101.800 \\
\text { employees (2016). } \\
\text { Distributor of personal com- } \\
\text { puters (PC) and PC equipment. } \\
\text { The product portfolio compris- } \\
\text { es business solutions, software, } \\
\text { peripheral equipment, end } \\
\text { users solutions, and services. } \\
\text { Customer participation and } \\
\text { customer feedback is the basis } \\
\text { for decision-making on the } \\
\text { products and services offered. } \\
\text { Dell seized the possibilities of } \\
\text { social web early in } 2006 \text { and } \\
\text { founded a dedicated corporate } \\
\text { "Social Media Listening } \\
\text { Command Centre" in } 2010 \text {. }\end{array}$ & $\begin{array}{l}\text { Founded 2002, Headquarter } \\
\text { in Leipzig, Germany, } 500 \\
\text { employees (2016). } \\
\text { Spreadshirt is a company for } \\
\text { on-demand prints on clothes } \\
\text { and accessories. The busi- } \\
\text { ness model is based on ac- } \\
\text { tively integrating the exter- } \\
\text { nal parties (community) into } \\
\text { the processes of marketing, } \\
\text { sales, and services. Spread- } \\
\text { shirt differentiates the com- } \\
\text { munity members into end } \\
\text { customers of the T-shirts } \\
\text { (customers) and into design- } \\
\text { ers, companies, or promoters } \\
\text { (sellers), but often communi- } \\
\text { ty members have both roles. }\end{array}$ & $\begin{array}{l}\text { Founded 1995, Headquarter in } \\
\text { Bonn, Germany, } 221.341 \text { em- } \\
\text { ployees (2016). } \\
\text { Deutsche Telekom AG (DT) is } \\
\text { a worldwide telecommunica- } \\
\text { tion company and a subsidiary } \\
\text { of Telekom AG, which serves } \\
\text { private and business customers } \\
\text { in Germany. The product port- } \\
\text { folio comprises fixed-line and } \\
\text { mobile telephony as well as } \\
\text { Internet and media services, } \\
\text { such as DSL and IPTV. By } \\
\text { now, the DT already has accu- } \\
\text { mulated several years of expe- } \\
\text { rience in Social Media and has } \\
\text { established a dedicated organi- } \\
\text { zational unit called the "Social } \\
\text { media Service Centre". }\end{array}$ \\
\hline \multirow{6}{*}{ 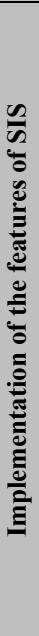 } & 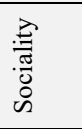 & $\begin{array}{l}\text { Focus on a community of follow- } \\
\text { ers. Focus on information ex- } \\
\text { change }\end{array}$ & $\begin{array}{l}\text { Focus on a community of } \\
\text { contributors. Focus on infor- } \\
\text { mation exchange and collabo- } \\
\text { ration }\end{array}$ & $\begin{array}{l}\text { Focus on a community of } \\
\text { contributors. Focus on in- } \\
\text { formation exchange and } \\
\text { collaboration }\end{array}$ & $\begin{array}{l}\text { Focus on a community of fol- } \\
\text { lowers. Focus on information } \\
\text { exchange }\end{array}$ \\
\hline & 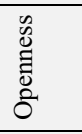 & $\begin{array}{l}\text { Dedicated employees and actors } \\
\text { in the market can be active. Focus } \\
\text { on dedicated internal and external } \\
\text { platforms }\end{array}$ & $\begin{array}{l}\text { The whole organization and } \\
\text { the market can be active on } \\
\text { different platforms. Focus on } \\
\text { internal and external platforms }\end{array}$ & $\begin{array}{l}\text { The market can be active on } \\
\text { the platform and dedicated } \\
\text { employees. Focus on internal } \\
\text { platforms }\end{array}$ & $\begin{array}{l}\text { Dedicated employees and the } \\
\text { whole market can be active. } \\
\text { Focus on internal platforms }\end{array}$ \\
\hline & 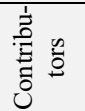 & $\begin{array}{l}\text { Employees have defined process- } \\
\text { es and dedicated external persons } \\
\text { can contribute }\end{array}$ & $\begin{array}{l}\text { All employees with a qualifi- } \\
\text { cation and all interested exter- } \\
\text { nals can contribute }\end{array}$ & $\begin{array}{l}\text { Dedicated employees and } \\
\text { community members can } \\
\text { contribute }\end{array}$ & $\begin{array}{l}\text { Employees have defined pro- } \\
\text { cesses and all interested exter- } \\
\text { nal persons can contribute }\end{array}$ \\
\hline & 官 苞 & UGC is shared and monitored & $\begin{array}{l}\text { UGC is stimulated, shared and } \\
\text { monitored }\end{array}$ & $\begin{array}{l}\text { UGC is stimulated, shared } \\
\text { and monitored }\end{array}$ & $\begin{array}{l}\text { UGC is stimulated, shared and } \\
\text { monitored }\end{array}$ \\
\hline & 方 & $\begin{array}{l}\text { Different Social Media platforms, } \\
\text { some Social CRM tools and a } \\
\text { CRM system is used, but not } \\
\text { integrated }\end{array}$ & $\begin{array}{l}\text { Different Social Media plat- } \\
\text { forms, a broad set of Social } \\
\text { CRM tools and a CRM system } \\
\text { is used and partially integrated }\end{array}$ & $\begin{array}{l}\text { Different Social Media plat- } \\
\text { forms, some Social CRM } \\
\text { tools and a CRM system is } \\
\text { used, but not integrated }\end{array}$ & $\begin{array}{l}\text { Different Social Media plat- } \\
\text { forms, some Social CRM tools } \\
\text { and a CRM system is used and } \\
\text { partly integrated }\end{array}$ \\
\hline & 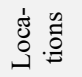 & $\begin{array}{l}\text { Online (in addition offline stores), } \\
\text { internal and external }\end{array}$ & Online, internal and external & Online, internal and external & $\begin{array}{l}\text { Online (in addition offline } \\
\text { stores), internal and external }\end{array}$ \\
\hline
\end{tabular}


Affected processes (refers to Q7, Q8 and Q9). Dell and Spreadshirt incorporated Social Media in almost all CRM processes, while DT and Cyberport concentrate on service and marketing related processes. The cases show that collaboration with customers, as in the case of Spreadshirt, can affect all processes, as long as the company is able to open up their processes. At Spreadshirt, customers can for example create offerings, create advertising, help other users and sell products. Dell shows a similar approach and treats for example web influencers as partners with dedicated resources, contact persons or events.

Connected with the collaboration is the process management and the need to track processes across Social Media platforms and between internal and external users. External actors can also perform tasks of process management as in the case of Spreadshirt, where for example partners initiate design and marketing processes and Spreadshirt supports the advertising and offers a shop. Dell and DT provide a forum where customers can search for solutions and initiate new services cases, which are taken up by employees.

The cases show, that tasks of internal and external users are linked. External users mainly interact with the business, while on the business side also the analysis, integration and CRM process related tasks are used. Thus calling for bi-directional integration of involved platforms within SIS where internal and external parties can initiate processes and share task related information, resources and competences. Dell, DT and Spreadshirt already support such tasks with dedicated systems (e.g. community platform) in addition to Social Media platforms and Social CRM tools. However, the integration of these systems is low.

Involved systems and integration (refers to Q10 and Q11). The cases show that social interaction and open collaboration require spaces for collaboration that enable users to exchange and create UGC. Spreadshirt, Dell and DT provide dedicated spaces for social interaction with customers and collaboration through own forums. Dell integrated activities between platforms with their own solution where service cases and involved parties are registered and information is distributed to related systems (e.g. service or team management). Spreadshirt provides a community platform to which activities and UGC on other platforms are linked. Users exchange structured (e.g. profiles) and unstructured data (e.g. UGC). In a collaboration process users may read and answer manually on Social Media, but for workflow automation and integration with other systems, the companies of all four cases use Social CRM tools and intermediary databases. Thus showing, that pure community platforms are insufficient and require, additionally, a processing and integration of data between involved platforms [42].

\section{Discussion about the design of SIS and contribution of Social CRM}

The analysis of the four cases affirms the observation that companies combine Social CRM, CRM and Social Media for realizing scenarios associated with SIS. However, they also show a low support on the IS level along with a punctual realization of these scenarios. An open and voluntary interaction as well as the outside-in perspective are not fully addressed in the cases and seem to require further integration of the three pillars. However, some observations can be obtained about the contribution of Social CRM for SIS oriented applications scenarios. Thus answering RQ3.

\subsection{Role of Social Media, CRM and Social CRM towards SIS}

The comparison of the cases shows that characteristics of SIS are present in all cases and relevant functionalities are spread across several IS. CRM oriented SIS need to incorporate the other CRM related IS for providing the means for social interaction and open collaboration, driven by firms, customers and as collaborative effort.

Social Media represent the basic platforms. They can be provided by companies or hosted by third parties. Firms may initiate communities (e.g. Dell, Spreadshirt or DT), but also customers may initiate communities (e.g. Experts that support Dell customers, external help communities for DT services) on them.

Social CRM tools provide access to data, insights into UGC on a detail and global level and provide means for management and interaction related to CRM tasks. They are used by companies (e.g. Dell Social Listing Command Centre) or by external actors (e.g. Influencers at the Dell, Partners of Spreadshirt).

CRM systems provide a comprehensive view on customers as well as functionalities for managing the relationship from a firm perspective. Nevertheless, Social Media, such as Facebook or LinkedIn, feature partially such functionalities and firms like Spreadshirt show that forums can be used partially as CRM system. However, CRM systems are crucial for linking with back-end and SCM systems.

The case analysis highlights that SIS foster social interaction between internal and external users with the aim to create opportunities for collaboration in CRM processes. While Social CRM already provides the means to interact with customers in CRM processes, they seem to be insufficient from the perspective of SIS. The case of Spreadshirt illustrates that an own community, which is connected with other systems (e.g. Web-shop or ERP systems), can provide a suffi- 
cient space for collaboration with external users. The case of Dell shows that interactions, collaboration and process management across different Social Media call for systems that integrate data and process flows in a SIS. Social Media platforms such as Facebook provide also SIS functionalities that are used in parallel.

\subsection{Observation about effects of SIS on CRM}

Fostering of strong and weak ties. Companies nourish their strong ties by involving the competencies of external users in process tasks or by pro-actively requesting support (e.g. Spreadshirt cooperates with customers in the product design and marketing, DT cooperates with customers in service management). At the same time, they create additional weak ties with customers and interested parties by following, recommending or staying in contact with updates during the usage phase. Several instruments are combined for that purpose: provision of regular information, presence on external platforms, moderation of discussions, selfservice abilities and open resources.

Complementing an inside-out with outside-in approach. The cases highlight, that companies with limited organizational structures and smaller integration degree also feature less opportunities for engagement with customers. Cyberport, for example, shows several examples for firm-driven engagement, but customerdriven engagement and true collaboration is limited[33]. However, small and large companies can benefit from opening themselves for input from customers. Dell, shows a mature Social CRM approach with a high integration degree and also provides several means for collaboration and taking up customer-driven engagement related to almost all CRM processes. Thus resulting in an organizational culture that is picking up ideas and discussions from customers and turning them in input for the optimization and transformation of services. Spreadshirt illustrates a similar approach with fewer systems and integration of touch points in a central place. Here customers, partners and employees share the same discussion platforms and are participating in workflows. Thus providing the company with constant feedback from the market about the product range, cooperation in product development or externalization of process tasks. It can be observed, that an outside-in approach relates with the engagement opportunities, which are explicitly addressed by SIS.

Extending the pool of information, resources and competencies. The SIS orientation provides companies with access to additional information, indirectly by analyzing UGC in the community and directly by asking the community for opinions, recommendation and others. In addition, resources (e.g. shops, UGC) are generated by the community passively and proactively.
Also the competencies within the community, such as skills in consulting or sales, technical knowledge or creativity can be used.

Collaboration in processes and production. An important asset is the collaboration in processes where tasks of the companies are complemented with tasks performed by community members. Thus reducing costs and increasing the capabilities. For example, as members of the Spreadshirt community advertise products and generate leads, the company is selling its products and providing the service. Telekom is supporting members of the community in answering service requests by providing information resources.

Service and product innovation. A high number of relationships within the community provide also new means for innovation. For example, Dell provides a place for the sharing and discussion of product and service ideas or the Telekom proactively shares new product ideas with the community and monitors the reactions and discussion. Cyberport and Spreadshirt monitor and moderate discussion about the product and service portfolio and distribute insights within the organization.

\subsection{Implications on the design of SIS}

On the strategy level, a SIS may affect all four Social CRM application areas. This comprises the discussion, creation and sharing of UGC through which information, resources and competencies are exchanged. Important is that this happens in both directions. For example, companies not only share information with customers, but customers generate information for the company. While Social CRM provides the basis for building up a SIS, companies seem to require a reevaluation and design of processes for opportunities to incorporate customers and other followers.

On the process level, SIS build upon existing CRM tasks in companies, but aim to provide users with the means to perform own tasks. Social CRM systems need to integrate or provide platforms for the gathering and interaction of customers, experts and businesses to access information about products, qualify demands, create offers, work in service requests and exchange feedback. Each participant should be free to join and to create and re-use the content. The cases illustrate that collaboration is already used in some CRM processes and others benefit indirectly through better access to knowledge, increased visibility through Social Media activities or support of external users in workflows. However, often as add-on and not on a regular basis. Social CRM systems need to unveil these opportunities as soon as they arise in the community.

On the system level, these activities and the underlying services need to be linked. The cases highlight, 
that a SIS do not need a single platform, but the integration of the main components for collaboration with supporting services from other systems such as CRM or Social Media Management. This not only allows automation, but to realize workflows across platforms. Spreadshirt presents such an example with the marketplace that is integrated with a forum and features CRM functionalities. Social CRM provides the means for monitoring, integration and performing interactions.

\subsection{Implications for business}

The research shows, that the concept of SIS expands the perspective of CRM behind the customerfacing processes to collaboration with the market. With an SIS based approach, companies may further stimulate the forming of relationship ties with relevant actors in the market as well as their utilization. This allows companies to improve the acquisition of information, to access more competencies and to collaborate with external entities. Thus, extending the tactical options in CRM and improving customer orientation [35]. The four cases show that small and large companies can follow this approach and that main challenges are the integration and governance of involved platforms, tools, processes and actors. Social CRM provides a good basis, but as the cases reaffirm, companies need to open up their processes and fully incorporate platforms outside of their control and ownership. Thus challenging the traditional perspectives behind CRM and Social CRM. Currently, system providers are starting to adopt this perspective in new functionalities (e.g. SAP C/4Hana Service Cloud based on Coresystems).

\section{Conclusions}

This research investigated the use and integration of Social Media in CRM from the perspective of SIS [6]. The paper compares SIS based on the concept of Schlagwein et al. [6] with the related concept of Social CRM. Based on a literature review and examination of four case studies it points out similarities and differences between the concepts. In addition it demonstrates an approach for analysing the design and contribution of SIS by applying a Social CRM framework [4]. Thus providing further insights into the customer facing design areas of SIS [6] and an approach for linking SIS and Social CRM related research. This research illustrates that the existing framework of SIS should be further detailed in its different design areas to provide a comprehensive analysis instrument and to guide further research and IS design.

The findings from the case examination show that SIS can be used not only for strengthen customer relationships (strong ties), but also expanding the capabili- ties of companies by fostering weak ties [7]. Thus supporting companies in the application of outside-in approaches [1]. SIS may extend CRM with a higher level of social interactions and open collaboration. Therefore, they build on the active integration of customers in tasks and processes and require features for community building and computer supported cooperative work. Existing systems in CRM, Social Media and Social CRM provide such functionalities, but they need to be bi-directionally integrated. The case examples illustrate that this integration does not need to be fully automated, but that a higher degree of automated integration aligns with more affected processes. A high level of engagement and collaboration as well as levering an outside-in perspective also not necessarily aligns with the extent of a Social CRM implementation.

However, because of the low number of analysed cases and the focus on e-commerce, the insights from this research about Social CRM and SIS are limited and further research is necessary. While Schlagwein et al. [6] differentiate the business value of SIS into five areas, our research indicates that already one example is very complex and multi-dimensional. For the development of a robust framework that guides the design, building and leveraging of new IS, the architecture and business value of SIS need further research. The insights of this research may provide a basis for the design of further qualitative and quantitative examinations of SIS.

The authors received financial support of this research by the Development Bank of Saxony (SAB) and the European Social Fund (ESF) within the project S2DES.

\section{References}

[1] K. Heinonen and T. Strandvik, "Customer-dominant Logic: Foundations and Implications", Journal of Services Marketing, 29 (2015), pp. 472-484.

[2] K. Heinonen, Social Media Activities: Understanding What Consumers Do in Social Media, in E. Y. Li, S. Loh, C. Evans and F. Lorenzi, eds., Organizations and Social Networking: Utilizing Social CRM to Engage Consumers, Business Science Reference, Hershey, P.A., 2013, pp. 1-15.

[3] P. Greenberg, "The Impact of CRM 2.0 on Customer Insight", Journal of Business \& Industrial Marketing, 25 (2010), pp. 410-419.

[4] R. Alt and O. Reinhold, "Social Customer Relationship Management (Social CRM) - Application and Technology", Business \& Information Systems Engineering, 4 (2012), pp. 287-291.

[5] M. Sigala, Social CRM Capabilities and Readiness: Findings from Greek Tourism Firms, in R. S. A. Inversini, ed., Information and Communication Technologies in Tourism 2016, Springer, Bilbao, Spain, 2016, pp. 309-322.

[6] D. Schlagwein, D. Schoder and K. Fischbach, Social Information Systems: Review, Framework, and Research Agenda, 32th International Conference on Information Systems (ICIS), Shanghai, 2011. 
[7] M. Granovetter, "The Strength of Weak Ties: A Network Theory Revisited", Sociological Theory, 1 (1983), pp. 201233.

[8] G. F. Khan, "Social Media-based Systems: An Emerging Area of Information Systems Research and Practice", Scientometrics, 95 (2013), pp. 159-180.

[9] R. Schmidt, R. Alt and S. Nurcan, Introduction to the Social Information Systems Minitrack, 51st Hawaii International Conference on System Science (HICSS), Hawaii, 2018. [10] R. Agarwal, A. Gupta and R. Kraut, "The Interplay Between Digital and Social Networks", Information Systems Research, 19 (2008), pp. 243-252.

[11] M. J. Leimeister, M. Huber, U. Bretschneider and H. Krcmar, "Leveraging Crowdsourcing: Activation-Supporting Components for IT-Based Ideas Competition", Journal of Management Information Systems, 26 (2009), pp. 197-224.

[12] B. Wehner, C. Ritter and S. Leist, "Enterprise Social Networks: A Literature Review and Research Agenda", Computer Networks, 114 (2017), pp. 125-142.

[13] R. Tilly, O. Posegga, K. Fischbach and D. Schoder, "Towards a Conceptualization of Data and Information Quality in Social Information Systems", Business \& Information Systems Engineering, 59 (2017), pp. 3-21.

[14] R. K. Yin, Case Study Research: Design and Methods, Sage Publications, London, 2009.

[15] K. Paulissen, K. Milis, M. Brengman, J. Fjermestad and J. Nicholas C. Romano, Voids in the Current CRM Literature, 40th Hawaii International Conference on System Science (HICSS), Hawaii, 2007.

[16] D. Peppers and M. Rogers, Managing Customer Relationships: A Strategic Framework, Wiley, Hoboken, 2004.

[17] H. Gebert, M. Geib, L. Kolbe and W. Brenner, "Knowledge-enabled Customer Relationship Management", Journal of Knowledge Management, 7 (2003), pp. 107-123.

[18] S. Vandermerwe, "How Increasing Value to Customers Improves Business Results", MIT Sloan Management Review, 42 (2000), pp. 27-37.

[19] J. O. Chan, "An Integrated Architecture for Enterprise Relationship Management", Communications of the IIMA, 8 (2008), pp. 55-66.

[20] M. Geib, L. M. Kolbe and W. Brenner, "Customer Relationship Management in Business Networks: Lessons from the Financial Services Industry in Germany and Switzerland", MIS Quarterly Executive, 4 (2005), pp. 247-260.

[21] R. Alt and T. Puschmann, Successful Practices in Customer Relationship Management, 37th Hawaii International Conference on System Sciences (HICSS), Hawaii, 2004.

[22] A. M. Kaplan and M. Haenlein, "Users of the World, Unite! The Challenges and Opportunities of Social Media", Business Horizons, 53 (2010), pp. 59-68.

[23] C. Li and J. Bernoff, Groundswell: Winning in a World Transformed by Social Technologies, Harvard Business Press, Boston, 2008.

[24] K. Trainor, J. Andzulis, A. Rapp and R. Agnihotri, "Social Media Technology Usage and Customer Relationship Performance: A Capability-based Examination of Social CRM", Journal of Business Research, 67 (2014), pp. 12011208.

[25] R. Faase, R. Helms and M. Spruit, "Web 2.0 in the CRM Domain: Defining Social CRM", International Journal of Electronic CRM, 5 (2011), pp. 1-22.
[26] L. Ang, "Community Relationship Management and Social Media", Journal of Database Marketing \& Customer Strategy Management, 18 (2011), pp. 31-38.

[27] N. Woodcock, A. Green and M. Starkey, "Social CRM as a Business Strategy", Journal of Database Marketing \& Customer Strategy Management, 18 (2011), pp. 50-64.

[28] T. Lehmkuhl and R. Jung, Towards Social CRM - Scoping the Concept and Guiding Research, 26th Bled eConference, Bled, 2013.

[29] K. Yoon and J. Sims, Integrating Social Media and Traditional CRM - Toward a Conceptual Framework for Social CRM Practices, in A. Ayanso and K. Lertwachara, eds., Harnessing the Power of Social Media and Web Analytics, IGI Global, Hershey PA, 2014, pp. 103-131.

[30] K. M. Swarts, K. Lehmann and G. K. Lewis, "The Use of Social Customer Relationship Management by Building Contractors: Evidence from Tasmania", Construction Management and Economics, 34 (2016), pp. 302-316.

[31] O. Reinhold and R. Alt, Social Customer Relationship Management: State of the Art and Learnings from Current Projects, 25th Bled eConference, Bled, 2012.

[32] P. Harrigan, G. Soutar, M. M. Choudhury and M. Lowe, "Modelling CRM in a Social Media Age", Australasian Marketing Journal, 23 (2015), pp. 27-37.

[33] W. Kunz, L. Aksoy, Y. Bart, K. Heinonen, S. Kabadayi, F. Ordenes, M. Sigala, D. Diaz and B. Theodoulidis, "Customer Engagement in a Big Data World", Journal of Services Marketing, 31 (2017), pp. 161-171.

[34] D. Mitussis, L. O’Malley and M. Patterson, "Mapping the Re-engagement of CRM with Relationship Marketing", European Journal of Marketing, 40 (2006), pp. 572-589.

[35] C. Grönroos, "Relationship Marketing: Strategic and Tactical Implications", Management Decision, 34 (1996), pp. 5-14.

[36] N. Letch, "Ecologies of Interests in Social Information Systems for Social Benefit", Information Technology \& People (2016), pp. 14-30.

[37] A. S. Lee, "Retrospect and Prospect: Information Systems Research in the Last and Next 25 Years ", Journal of Information Technology \& Tourism, 25 (2010), pp. 336-348. [38] E. Limaj, E. W. N. Bernroider and J. Choudri, "The Impact of Social Information System Governance, Utilization, and Capabilities on Absorptive Capacity and Innovation: A Case of Austrian SME's", Information \& Management, 53 (2016), pp. 380-397.

[39] A. Theotokis and G. Doukidis, When Adoption Brings Addiction: A Use-Diffusion Model for Social Information Systems, 30th International Conference on Information Systems (ICIS), Phoenix, 2009, pp. 1-12.

[40] H. Österle and D. Blessing, Business Engineering Mod$\mathrm{el}$, in H. Österle and R. Winter, eds., Business Engineering, Springer, Berlin, 2002, pp. 65-86.

[41] C. Baethge, J. Klier and M. Klier, "Social CommerceState-of-the-Art and Future Research Directions", Electronic Markets, 26 (2016), pp. 269-290.

[42] R. Tilly, O. Posegga, K. Fischbach and D. Schoder, What is Quality of Data and Information in Social Information Systems? Towards a Definition and Ontology, ICIS, Fort Wort, 2015, pp. 1-22.

[43] M. Granovetter, "The Strength of Weak Ties", The American Journal of Sociology, 78 (1973), pp. 1360-1380. 